\title{
Kajian Morfologi Ikan Timpakul (Famili Gobiidae) dari Dua Tipe Ekosistem Mangrove yang Berbeda
}

\author{
Anang Kadarsah $^{1}$, Krisdianto ${ }^{1}$, Ika Oksi Susilawati ${ }^{1}$ \\ ${ }^{1}$ Program Studi Biologi FMIPA Universitas Lambung Mangkurat (ULM), Jl A Yani Km 35,8 Banjarbaru, \\ Kaimantan Selatan 70714
}

Penulis untuk Korespondensi/E-mail: anangkadarsah@ulm.ac.id

\begin{abstract}
Abstrak - Kajian ekologi hewan eksotik seperti ikan Timpakul pada ekosistem mangrove penting digali selain memperkaya pengetahuan juga menjadi landasan pengelolaan biodiversitas secara keseluruhan. Tujuan penelitian ini membandingkan kelimpahan dan morfologi ikan Timpakul (Famili: Gobiidae) pada dua tipe ekosistem mangrove di Muara Kuala Tambangan dan Pantai Pagatan Besar, Kabupaten Tanah Laut, Kalimantan Selatan. Survei data dan penangkapan ikan menggunakan jaring 1 meter x 10 meter dengan 10 kali ulangan. Hasil penelitian ditemukan tiga jenis ikan Timpakul yakni: Boleophthalmus pectinirostris, Periophthalmodon schlosseri, dan Boleophthalmus boddarti. Vegetasi Rhizophora sp. dan Bruguierasp. dominan pada Muara Kuala Tambangan (65,8\% dan 34,2\%), sedangkan di Pantai Pagatan Besar didominasi Bruguiera Sp. (50,8\%)dan Avicennia sp. (49,2\%). Persentase kehadiran Boleopthalmus pectinirostris tertinggi di Pantai Pagatan Besar (64\%), sedangkan di Muara Kuala Tambangan lebih dominan Boleophthalmus boddarti (71,11\%). Berdasarkan lima karakter utama morfologi terpilih (SL=panjang standar, HL=panjang kepala, FDFB=Panjang dasar sirip dorsal pertama, SDFB=Panjang dasar sirip dorsal kedua, dan VFL=Panjang Sirip Ventral : satuan $\mathrm{mm})$, rerata tertinggi dijumpai pada Periophthalmodon schlosseri $(\mathrm{SL}=167,50: \mathrm{HL}=46,67: \mathrm{FDFB}=22,17$ : SDFB=35,33 dan VFL=24,17), disusul Boleophthalmus pectinirostris (SL=131,89:HL=31,22: FDFB=21,67:SDFB=49,67 dan VFL=17,11) kemudian yang terakhir Boleophthalmus boddarti ( $\mathrm{SL}=130,55: \mathrm{HL}=30,64: \mathrm{FDFB}=18,27: \mathrm{SDFB}=52,73$ dan $\mathrm{VFL}=16,73)$. Persentase rerata kandungan substrat (pasir:debu:liat) di Muara Kuala Tambangan 17,26\%:77,52\%:5,21\% sedangkan di Pantai Pagatan Besar perbandingannya adalah 3,52\%: 85,46\%:11,03\%.
\end{abstract}

Abstract - Ecological studies of exotic animals such as Timpakul fish (Family of Gobiidae) in mangrove ecosystems is important to enriching the knowledge and for the overall of biodiversity management. The purpose of this study was to compare the abundance and morphology of Timpakul fish in two types of mangrove ecosystems. especially in the Village of Kuala Tambangan and Pagatan Besar, Tanah Laut Regency, South Kalimantan. Survey data and fishing was used by 1 meter $x 10$ meters of nets with 10 replications. Its found about three types of Timpakul fish, ie: Boleophthalmus pectinirostris, Periophthalmodon schlosseri, and Boleophthalmus boddarti. Rhizophora sp. and Bruguiera Sp. types vegetation were dominantly in Kuala Tambangan estuary $(65.8 \%$ and $34.2 \%)$, while in Pagatan Besar beach it is dominated by Bruguiera Sp. $(50.8 \%)$ and Avicennia sp. $(49.2 \%)$. The highest percentage attendance in Pagatan Besar Beach is found for Boleopthalmus pectinirostris (64\%), while in Kuala Tambangan Estuary was dominantly by Boleophthalmus boddarti $(\mathbf{7 1 . 1 1 \% )}$. Based on the five main morphological characters ( $\mathrm{SL}=$ standard length, $\mathrm{HL}=$ head length, FDFB=first dorsal fin base, SDFB=second dorsal fin base length, and VFL=Ventral fin length: in $\mathrm{mm}$ of unit), so the highest average was found in Periophthalmodon schlosseri $(\mathrm{SL}=167.50: \mathrm{HL}=46.67: \mathrm{FDFB}=22.17: \mathrm{SDFB}=35.33$ and $\mathrm{VFL}=$ 24.17). It is followed by Boleophthalmus pectinirostris $(\mathrm{SL}=131.89$ : $\mathrm{HL}=31.22: \mathrm{FDFB}=21.67: \mathrm{SDFB}=$ 49.67 and VFL = 17.11). Then the lowest is Boleophthalmus boddarti $(\mathrm{SL}=130.55: \mathrm{HL}=30.64:$ FDFB $=$ 18.27: $\mathrm{SDFB}=\mathbf{5 2 . 7 3}$ and $\mathrm{VFL}=\mathbf{1 6}, \mathbf{7 3}$ ). Substrate content (sand: dust: clay) percentage average in Kuala Tambangan estuary is 17.26\%:77.52\%:5.21\% while in Pagatan Beach the ratio is 3.52\%: 85.46\%: $11.03 \%$.

Keywords - Abundance, Mangrove, Morphology, Mudskipper 


\section{PENDAHULUAN}

$\mathrm{M}$ eskipun kekayaan jenis vegetasi mangrove tidak sebanyak ditemukan pada ekosistem terestrial lainnya, namun ternyata mangrove memiliki nilai yang sangat tinggi, diantaranya mangrove merupakan tempat yang ideal untuk mempelajari biodiversitas dan fungsi ekosistem [1]. Selain itu, berdasarkan karakter hidrologisnya, mangrove berfungsi sebagai penahan banjir, dan pengisi air bawah tanah serta permukaan. Dari sisi fungsi biogeokimia mangrove antara lain berfungsi untuk menyimpan dan melepaskan nutrien, serta mempertahankan salinitas dalam air dan tanah. Sedangkan dalam fungsi ekologisnya mangrove menjadi tempat pemijahan dan habitat yang dimanfaatkan sejumlah organisme; tempat pemeliharaan tumbuhan, hewan, dan mikroorganisme; keanekaragaman hayati; serta keragaman struktur dan bentang alam [2]. Semua hal itu tidak terlepas dari keberadaan sedimen yang terperangkap akar mangove dan menjadikannya sebagai tempat subur serta kaya bahan organik [3], lalu menjadi habitat berbagai hewan penting seperti ikan dan juga ecosystem engineer seperti tiram dan teritip [4].

Dari sekitar 66.650 hektar hutan mangrove di Provinsi Kalimantan Selatan, yang dimiliki Kabupaten Tanah Laut saat ini seluas 3.000 hektare dan masih terjaga kelestariannya [5]. Dijumpai beberapa lokasi istimewa, yakni ekosistem mangrove di muara Desa Kuala Tambangan seluas 20 hektar dan di pantai Desa Pagatan Besar seluas 7,4 hektar [6]. Secara administratif luas wilayah desa Kuala Tambangan adalah 5.920 hektar, sedangkan Desa Pagatan Besar luas wilayahnya ialah 4.540 hektar [7]

Ikan Timpakul atau Gelodok atau Tembakul atau Mudskippers (Famili Gobiidae) adalah salah satu jenis ikan yang umum dijumpai pada ekosistem mangrove dan mampu hidup pada habitat pasang surut berlumpur [8]. Keunikan ikan ini mampu beradaptasi dengan pola hidup menyerupai amfibi [9] yakni mampu hidup didarat sehingga sering disebut sebagai ikan amphibious [10]. Secara ekologis Timpakul penting kegunaannya sebagai 'biomarker' habitat perairan pantai yakni agen monitoring kandungan polyachrilic hydrocarbon atau PAH [11]

Melihat besarnya potensi sumber daya ikan Timpakul terutama yang berada di dalam kawasan hutan mangrove di Muara Kuala Tambangan dan
Pantai Pagatan Besar yang belum optimal serta masih kurangnya informasi bioekologi ikan eksotik seperti Timpakul, maka diperlukan penggalian informasi tersebut. Selain memperkaya pengetahuan juga menjadi landasan pengelolaan habitat secara keseluruhan. Dengan demikian tujuan penelitian ini membandingkan kelimpahan dan morfologi ikan Timpakul (Famili: Gobiidae) pada dua tipe ekosistem mangrove yang berada di muara dan pesisir pantai Kabupaten Tanah Laut, Kalimantan Selatan.

\section{METODE PENELITIAN}

\section{Desain, tempat dan waktu}

Desain penelitian ini menggunakan metode pengamatan secara langsung digunakan untuk menentukan kondisi vegetasi dan jenis substrat serta menghitung kehadiran dan morfologi (morfometri) Timpakul dari ekosistem mangrove. Tempat penelitian berada dua tempat yakni Muara Desa Kuala Tambangan dan Pantai Desa Pagatan Besar (Gambar 1). Waktu penelitian berlangsung dari bulan April sampai dengan bulan Juni 2018

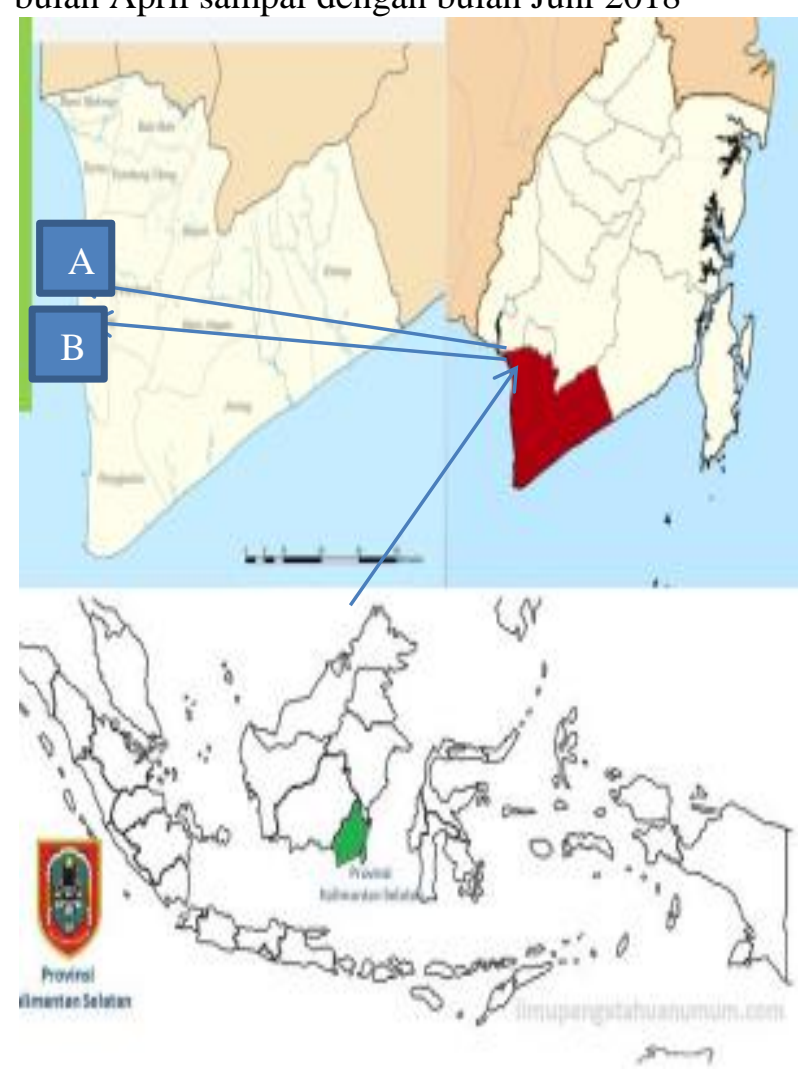

Gambar 1. Lokasi penelitian di Desa Kuala Tambangan dan Desa Pagatan Besar, Kabupaten Tanah Laut.

\section{Jumlah dan cara pengambilan sampel}

Pengumpulan data jenis dan kelimpahan vegetasi diperoleh melalui pengukuran pada sejumlah plot 
berukuran 10 meter x 10 meter. Pengujian tekstur substrat dengan menggunakan metode Hydrometer Boyoucous di Balai Penelitan Tanaman Rawa Banjarbaru.

Pengamatan kehadiran ikan Timpakul diperoleh melalui penangkapan menggunakan jaring yang dibentangkan berukuran 1 meter x 10 meter disertai ulangan sebanyak 10 kali. Pemasangan jaring dilakukan ketika air sedang surut, dan penangkapan menunggu ketika ikan Timpakul tersebut keluar dari sarangnya.

\section{Jumlah dan cara pengumpulan data}

Untuk keperluan pengukuran morfologi, ikan Timpakul difiksasi menggunakan formalin $4 \%$ dan diawetkan dalam larutan alkohol 70\% [12]. Pengukuran karakter morfologi meliputi studi morfometrik, meristik dan karakter khusus ikan. Karakter morfometrik merupakan ciri yang berkaitan dengan ukuran atau bagian tubuh ikan misalnya panjang total dan panjang baku. Karakter meristik adalah ciri yang berkaitan dengan jumlah bagian tubuh dari ikan, misalnya jumlah sisik pada garis rusuk, jumlah jari-jari keras dan lemah pada sirip punggung [13]

Dalam penelitian ini karakter morfometri ikan Timpakul berpedoman terhadap penelitian mengenai studi morfologi ikan Timpakul (Gobiidae - Oxudercinae) sebagai upaya karakterisasi biodiversitas lokal Pulau Tarakan [14]. Dalam makalah tersebut dinyatakan ada lima karakter morfometeri utama dan terpilih yang bernilai signifikasi 0.000 (berbeda sangat nyata/sangat signifikan). menggunakan uji Wilks Lamda. Kelima karakter terpilih tersebut adalah SL: panjang standar, HL: panjang kepala, FDFB: panjang dasar sirip dorsal pertama, SDFB: panjang dasar sirip dorsal kedua, dan VFL: panjang sirip ventral.

\section{Pengolahan dan Analisis data}

Analisis deksriptif kuantitatif digunakan untuk menghitung kelimpahan vegetasi dan kehadiran jenis Timpakul pada ekosistem mangrove. Sedangkan analisis perbedaan kondisi substrat, kehadiran jenis, dan karakter morfometri diuji dengan Paired Samples T-Test dan menggunakan Software GNU PSPP 1.0.1.

\section{HASIL DAN PEMBAHASAN}

\section{Perbandingan Struktur Vegetasi}

Hasil pengamatan seperti ditampilkan pada Gambar 2. menunjukkan ada dua jenis vegetasi yang dominan ditemukan pada muara Desa Kuala Tambangan yaitu Rhizophora sp. $(65,2 \%)$ dan Bruguiera sp. (34,8\%), sedangkan di Pantai Desa Pagatan Besar lebih didominasi oleh jenis Bruguiera Sp. (50,8\%) dan Avicennia sp. (49,2\%).

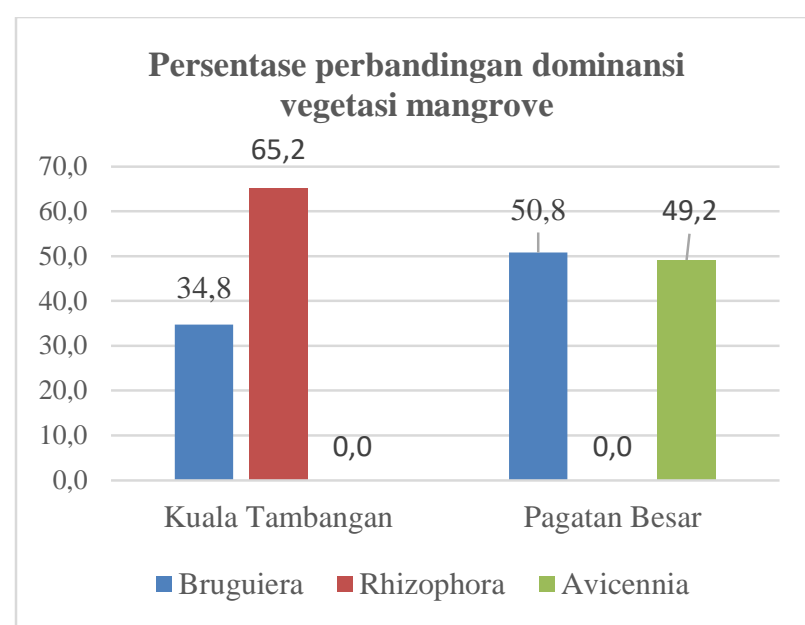

Gambar 2. Perbandingan dominansi jenis vegetasi mangrove yang ditemukan di muara Desa Kuala Tambangan dengan pantai Desa Pagatan Besar Dilihat dari segi dominansi vegetasi maka hasil yang diperoleh dari penelitian menunjukkan nilai yang lebih kecil bila dibandingkan dengan penelitian Kadarsah dan Choesin [15], dimana komposisi vegetasi dari penelitian ini bervariasi dan di bawah 100\% sedangkan penelitian Kadarsah dan Choesin [15] seluruhnya (100\%). Hal ini disebabkan oleh penerapan sistem silvofishery mangrove yang sengaja ditanam jenis tertentu (Rhizophora Sp.) sehingga umurnya dapat diketahui dengan pasti.

\section{Perbandingan Tekstur Tanah}

Hasil pengujian tekstur substrat menunjukkan bahwa kadar pasir di muara Desa Kuala Tambangan lebih tinggi $(17,26 \%)$ dibandingkan pantai Desa Pagatan Besar $(3,52 \%)$. Sedangkan nilai $\mathrm{pH}$, kadar debu dan liat di muara Desa Kuala Tambangan justru lebih rendah daripada pantai Desa Pagatan Besar (Tabel 1) 
Tabel 1. Hasil uji rerata tekstur dan $\mathrm{pH}$ tanah di muara Kuala Tambangan dan pantai Pagatan Besar

\begin{tabular}{lccc}
\hline \multirow{2}{*}{ Parameter } & \multicolumn{2}{c}{ Nilai rerata (\%) } & Paired \\
\cline { 2 - 3 } & $\begin{array}{c}\text { Kuala } \\
\text { Tambangan }\end{array}$ & $\begin{array}{c}\text { Pagatan } \\
\text { Besar }\end{array}$ & $\begin{array}{c}\text { Sampl } \\
\text { e test }\end{array}$ \\
\hline \% Pasir & 17,26 & 3,52 & 0,059 \\
\% Debu & 77,52 & 85,46 & 0,189 \\
\% Liat & 5,21 & 11,03 & 0,00 \\
$\mathrm{pH}$ & 6,15 & 7,44 & 0,00 \\
\hline
\end{tabular}

Sumber: Balai Penelitan Tanaman Rawa Banjarbaru,

2018

Hasil uji paired sample correlations setiap parameter tekstur dan $\mathrm{pH}$ menunjukkan bahwa tidak ada perbedaan signifikan antara kadar pasir dan debu di muara Desa Kuala Tambangan dibandingkan pantai Desa Pagatan Besar (nilai Sig.(2-tailed) 0,059 dan 0,189). Sebaliknya kadar liat dan nilai $\mathrm{pH}$ menunjukkan perbedaan signifikan (Sig.(2-tailed) 0,00 dan 0,00). Tidak semua kondisi hutan mangrove yang berada di dalam kawasan muara Sungai Barito teksturnya adalah berlumpur seperti hasil pengamatan Hidayaturrahmah dan Muhamat [10]. Namun beberapa tempat tertentu seperti data dari pantai Desa Tabanio dijumpai tekstur tanah yang dominan adalah berpasir dengan kadar sebanyak 95,52 - 97,42\% [16].

\section{Perbandingan Kelimpahan Timpakul}

Pada muara Kuala Tambangan rerata kelimpahan tertinggi adalah Boleophthalmus pectinirostris (3,2 individu/plot) sedangkan di pantai Pagatan Besar adalah Boleophthalmus boddarti (3,2 individu/plot). perbandingan indeks keanekaragaman Simpson muara Kuala Tambangan dengan pantai Pagatan Besar adalah 0,51: 0,45 sedangkan perbandingan keanekaragaman relatif (Evennes) nilainya 0,74 berbanding 0,66.

Bila dibandingkan dengan hasil penelitian serupa maka terdapat perbedaan hasil pada jenis Timpakul yang dominan ditemukan dari lokasi penelitian, dimana jenis yang dominan adalah Boleophthalmus pectinirostris pada muara dan Boleophthalmus pectinirostris pada pantai, sedangkan penelitian Nugroho [14] menunjukkan jenis yang dominan adalah Periopthalmodon freycineti baik pada habitat pemukiman penduduk, lahan terbuka maupun daerah mangrove.

Pada penelitian ini ditemukan 3 (tiga) jenis ikan Timpakul pada ekosistem mangrove di muara Desa Kuala Tambangan dan daerah pantai di Desa Pagatan Besar yaitu Boleophthalmus pectinirostris,
Periophthalmodon schlosseri, dan Boleophthalmus boddarti (Tabel 2).

Tabel 2. Rerata perhitungan kelimpahan ikan Timpakul pada ekosistem mangrove di muara Kuala Tambangan dan pantai Pagatan Besar (plot ukuran $10 \mathrm{~m} \times 10 \mathrm{~m}$ )

\begin{tabular}{cccc}
\hline \multirow{2}{*}{ Parameter } & \multicolumn{3}{c}{ Muara Kuala Tambangan } \\
\cline { 2 - 4 } & BoPec & PeSc & BoBod \\
\hline K & 3,2 & 1,5 & 0,3 \\
KR & 0,64 & 0,30 & 0,06 \\
$\mathrm{D}(\%)$ & 64 & 30 & 6 \\
\hline
\end{tabular}

\begin{tabular}{cccc} 
D $(\%)$ & 64 & 30 & 6 \\
\hline IS & \multicolumn{3}{c}{0,51} \\
\hline E & \multicolumn{3}{c}{0,74} \\
Parameter & BoPec & PeSc & BoBod \\
\cline { 2 - 4 } & 0,3 & 1 & 3,2 \\
K & 0,07 & 0,22 & 0,71 \\
KR & 6,67 & 22,22 & 71,11 \\
D $(\%)$ & 0,45 \\
\hline IS & \multicolumn{3}{c}{0,66} \\
\hline E
\end{tabular}

Keterangan : K=Kelimpahan, KR=Kelimpahan Relatif, Dominansi=D, IS=Indeks Simpsons, E=Evennes, BoPec $=$ Boleophthalmus pectinirostris, $\mathrm{PeSc}=$

Periophtalmodon schlosseri, dan Bobod = Boleophthalmus boddarti.

\section{Jenis Boleophthalmus pectinirostris}

Boleophthalmus pectinirostris (atau 'Great Bluespotted Mudskipper) bisa ditemukan pada habitat terbuka di ekosistem mangrove, seperti pada lumpur daerah muara laut, dan bagian punggung mangrove yang jarang tertutup. Jenis ini paling mudah diidentifikasi di lapangan dengan adanya bintikbintik biru halus pada sirip dorsal depan, dan terdapat pola pengaturan bintik biru seperti tanda hubung pada sirip dorsal kedua, yang tersusun rapi dalam garis vertikal dan horizontal [17]. Pita gelap sering terlihat di sisi-sisi, dan pada beberapa populasi kulit di bawah mata berwarna biru pucat (Gambar 3).

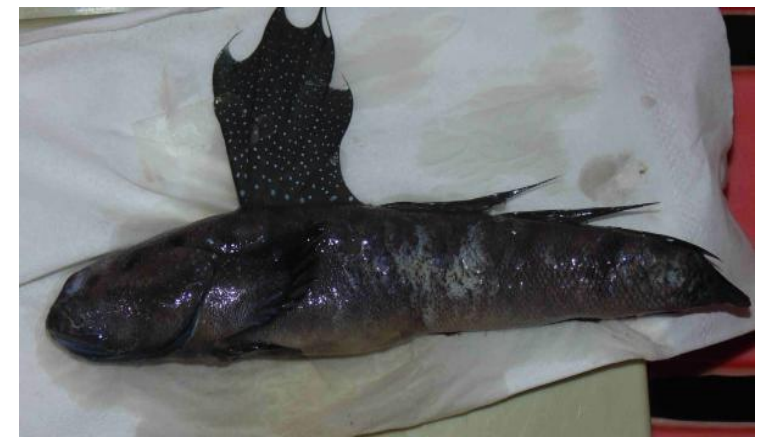

Gambar 3. Timpakul jenis Boleophthalmus pectinirostris (Sumber : Koleksi Pribadi, 2018) 


\section{Jenis Periophthalmodon schlosseri}

Jenis Periophthalmodon schlosseri, dalam bahasa Inggris disebut giant mudskipper adalah salah satu anggota genus Periophthalmodon yang memiliki tubuh yang besar. Panjang tubuhnya dapat mencapai $27 \mathrm{~cm}$, sedangkan kebanyakan dari ikan Timpakul lainnya mencapai $25 \mathrm{~cm}$. Ikan Timpakul yang terbesar mampu mencapai $50 \mathrm{~cm}$. Jenis Periophthalmodon schlosser memiliki beberapa ciri khusus, [18] diantaranya bentuk tubuh yang panjang, mata yang saling berdekatan diatas kepala yang besar, adanya bagian tubuh (sirip dada) digunakan untuk bergerak di darat. Kepala dan batang tubuh berwarna biru keabu-abuan sampai cokelat kekuningan dengan bagian bawah abu-abu (Gambar 4.).

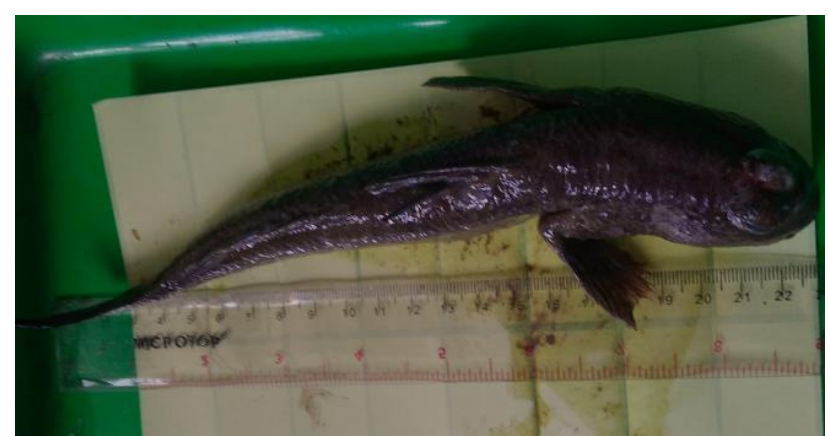

Gambar 4. Timpakul jenis Periophtalmodon schlosseri (Sumber : Koleksi Pribadi, 2018)

\section{Jenis Boleophthalamus boddarti}

Jenis ketiga yang ditemukan pada ekosistem mangrove adalah Boleophthalamus boddarti. Ikan ini memiliki ciri badan dan sirip punggung yang berwarna biru mengkilap dan terkadang berwarna biru kehijauan. Tubuhnya memiliki garis berwarna hitam kecoklatan, bagian kepala dipenuhi bintik berwarna kebiruan serta garis hitam, sedangkan pada bagian bawah tubuhnya berwarna putih [14] (Gambar 5.).

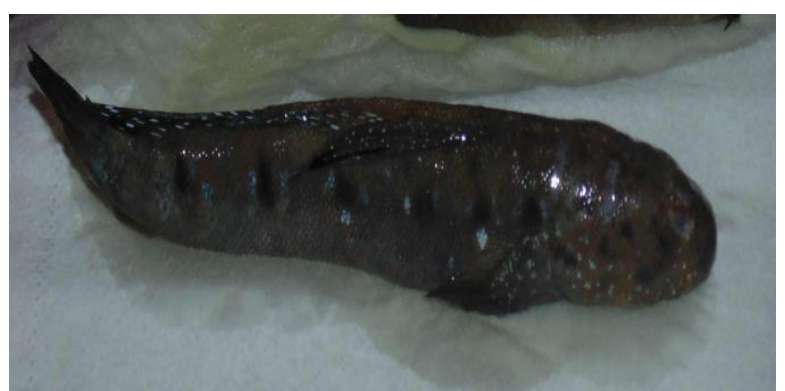

Gambar 5. Timpakul jenis Boleophthalmus boddarti (Sumber : Koleksi Pribadi, 2018).

\section{Karakter Morfologi (Morfometrik)}

Studi morfometrik dan meristik merupakan salah satu cara untuk melihat pengelompokan populasi ikan, selain untuk identifikasi [19]. Hasil pengamatan menunjukkan nilai tertinggi untuk lima parameter morfometri utama (SL,HL,FDFB,SDFB, dan VFL) tertinggi pada Periophthalmodon schlosseri. Tercatat nilai rerata panjang standar / SL untuk Periophthalmodon schlosseri adalah 167,50 $\mathrm{mm}$, selanjutnya Boleophthalmus pectinirostris sekitar 167,50 mm, dan terkecil Boleophthalmus boddarti sebesar 167,50 mm (Gambar 6.).

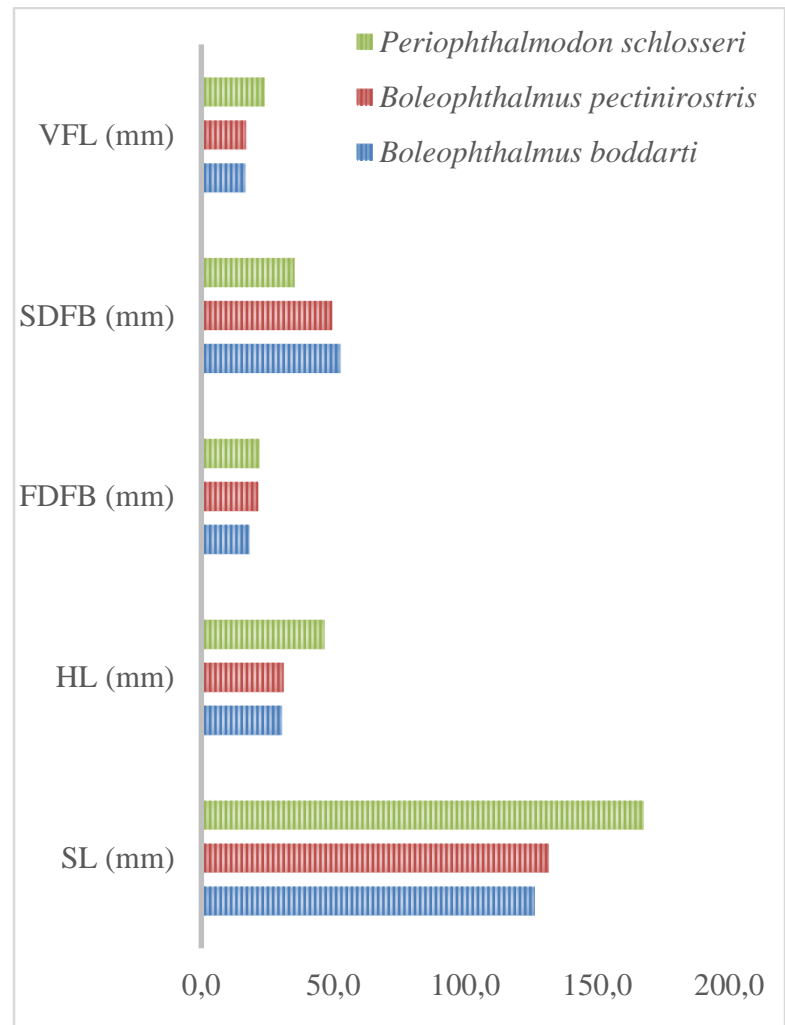

Gambar 6. Perbandingan morfologi (morfometri) jenis Boleophthalmus pectinirostris, Periophthalmodon schlosseri, dan Boleophthalmus boddarti. Keterangan : $\mathrm{SL}=$ panjang standar; $\mathrm{HL}=$ panjang kepala $; \mathrm{FDFB}=$ Panjang dasar sirip dorsal pertama $;$ SDFB = Panjang dasar sirip dorsal kedua, dan VFL = Panjang Sirip Ventral ; satuan mm).

Bila dibandingkan dengan hasil Nugroho [14] terlihat bahwa karakter morfometri ikan Periophthalmodon schlosseri lebih besar dibandingkan Periopthalmodon freycineti. Tercatat SL : HL : FDFB : SDFB : VFL (dalam satuan mm) menunjukkan bahwa morfometri jenis Periophthalmodon schlosseri adalah 167,5 : 46,7 : $22,2: 35,3: 24,2$ sedangkan nilai Periopthalmodon freycineti adalah $152,4: 40,2: 14,6: 30,0: 19,7$. 
Kelebihan dari penelitian ini adalah berhasil mendeskripsikan karakter mangrove berdasarkan vegetasi, substrat, dan perbandingan morfometri ikan yang terbesar. Kekurangan dari penelitian ini adalah belum menjelaskan korelasi antara tipe vegetasi dan substrat dengan dengan kelimpahan dan parameter morfometri secara khusus. Rekomendasi untuk penelitian selanjutnya adalah pengukuran meristematik dan ciri khusus yang dimiliki ikan Timpakul sebagai penanda pencemaran logam berat.

\section{KESIMPULAN}

Vegetasi dominan pada ekosistem mangrove Muara Kuala Tambangan adalah Rhizophora sp. $(65,8 \%)$ dan kadar substrat debu (77,52\%) sedangkan vegetasi di Pantai Pagatan Besar adalah Bruguiera sp. $(50,2 \%)$ dengan kadar debu sebanyak 85,46 .

Dari tiga jenis ikan Timpakul yang ditemukan yakni : Boleophthalmus pectinirostris, Periophthalmodon schlosseri, dan Boleophthalmus boddarti, jenis Boleophthalmus boddarti lebih dominan di Muara Kuala Tambangan (71,11\%) sedangkan Boleopthalmus pectinirostris terbanyak ditemukan di Pantai Pagatan Besar (64\%).

Rerata tertinggi lima karakter utama morfologi terpilih $(\mathrm{SL}=$ panjang standar; $\mathrm{HL}=$ panjang kepala ; FDFB = Panjang dasar sirip dorsal pertama ; $\mathrm{SDFB}=$ panjang dasar sirip dorsal kedua, dan $\mathrm{VFL}=$ panjang sirip ventral), ditemukan pada Periophthalmodon schlosseri disusul Boleophthalmus pectinirostris dan terakhir Boleophthalmus boddarti.

\section{UCAPAN TERIMA KASIH}

Ucapan Terimakasih disampaikan kepada Kementrian Riset teknologi dan Pendidikan Tinggi yang telah mendanai penelitian inii melalui skema penelitian dasar unggulan perguruan tinggi (PDUPT) untuk pendanaan tahun 2018.

\section{REFERENSI}

[1] E. C. Ashton, D. J. Macintosh, and P. J. Hogarth, A baseline study of the diversity and community ecology of crab and molluscan macrofauna in the Sematan mangrove forest, Sarawak, Malaysia," $J$. Trop. Ecol., vol. 19, no. 2, pp. 127-142, 2003.
[2] M. S. N. Islam, Cultural Landscape Changing due to Anthropogenic Influences on Surface Water and Threats to Mangrove Wetland Ecosystems: A Case Study on the Sundarbans, Bangladesh., 2008.

[3] P. Hogart, The Biology of Mangroves and Seagrasses. New York: Oxford University Press, 2007.

[4] N. C. Duke, Rhizophora apiculata, R. mucronata, R. stylosa, R. $\times$ annamalai, R. $\times$ lamarckii (Indo-West Pacific stilt mangroves), ver. 2.1. In: Elevitch, C.R. (ed.). Species Profiles for Pacific Island Agroforestry, Hawai'i., 2006. [Online]. Available: http://www.traditionaltree.org. [Diaskes pada 02 September 2018].

[5] Arianto, "Tanah Laut Miliki 3.000 Hektare Hutan Mangrove," 2016. .

[6] M. A. Soendjoto and P. Arifin, "Hutan Mangrove Pegatan Besar Kalimantan Selatan: Vegetasi dan Manfaatnya bagi Masyarakat," Mns. dan Lingkung., vol. 17, no. PPLH UGM, Yogyakarta, pp. 42-51, 1999.

[7] BPS, Tanah Laut Dalam Angka. Pelaihari: Badan Pusat Statistik Tanah Laut, 2013.

[8] E. O. Murdy, A taxonomic revision and cladistic analysis of the oxudercine gobies (Gobiidae: Oxudercinae), Rec. Aust. Museum, Suppl., vol. 11, pp. 1-93, 1989.

[9] J. B. Graham, Air-breathing Fishes: Evolution, Diversity, and Adaptation. San Diego: Academic Press, 1997.

[10] Hidayaturrahmah and Muhamat, Habitat Ikan Timpakul (Periophthalmodon Schlosseri) di Muara Sungai Barito, Enviro Sci., vol. 9, no. ISSN 1978-8096, pp. 134 139, 2013

[11] M. Sinaei and A. Mashinchian, Polycyclic Aromatic Hydrocarbons In The Coastal Sea Water, The Surface Sediment And Mudskipper Boleophthalmus dussumieri From Coastal Areas Of The Persian Gulf: Source Investigation, Composition Pattern And Spatial Distribution, J. Environ. Heal. Sci. Eng., vol. 12 (1), no. https://doi.org/10.1186/2052-336X-12-59, pp. $1-11,2014$.

[12] S. N. K. \& S. W. Kottelat, M., A.J. Whitten, Ikan Air Tawar Indonesia Bagian Barat dan Sulawesi. Jakarta: Periplus Edition (HK) Ltd. Bekerjasama dengan Proyek EMDI, Kantor Menteri Negara Kependudukan dan Lingkungan Hidup Republik Indonesia, Jakarta, 1993. 
[13] R. Affandi, S. S. Djadja, M. F. Rahardjo, and Sulistiono, Iktiologi, Suatu Pedoman Kerja Laboratorium. Bogor: IPB Press, 1992.

[14] E. D. Nugroho, Ibrahim, D. A. Rahayu, and D. Rupa, "Studi Morfologi Ikan Timpakul (Gobiidae - Oxudercinae) Sebagai Upaya Karakterisasi Biodiversitas Lokal Pulau Tarakan," J. Harpodon Borneo, vol. Vol.9. No., no. ISSN : 2087-121X, pp. 46-57, 2016.

[15] A. Kadarsah and D. Choesin, "Pengaruh Umur Tanam Terhadap Struktur Vegetasi dan Produksi Jatuhan Serasah Mangrove Rhizophora sp.," Bioscientiae, vol. 10 No.1, no. Januari 2013 ISSN 1693-4792, pp. 5669, 2013.

[16] A. Kadarsah, "Identifikasi Karakter Lansekap Dan Aktivitas Antropogenik Dalam Upaya Konservasi Kerang Kapah (Polymesoda Erosa ) Di Pesisir Pantai Desa Tabanio," Semin. Nas. Lingkung. Lahan Basah, 2017.
[17] N. Baker, "Great Blue-spotted Mudskipper," 2018. [Online]. Available: https://www.ecologyasia.com/verts/fishes/gr eat-blue-spotted-mudskipper.htm. [Diaskes pada 09 Agustus 2018].

[18] M. Burton and R. Burton, International Wildlife Encyclopedia. New York: Marshall Cavendish, 2002.

[19] S. H. Nasution, S. D. S. Sulistiono, and G. S. Haryani, "Variasi Morfologi Ikan Endemik Rainbow Selebensis (Telmatherina celebensis Boulenger) Di Danau Towuti, Sulawesi Selatan," J. Akuakultur Indones., vol. 3, no. 2, pp. 5-11, 2004. 